Volume 2 Nomor 2 Desember 2017 hal 130-142

Avaliable online at: http://e-journal.unipma.ac.id/index.php/gulawentah

\title{
DAMPAK DOPARI TERHADAP SIKAP SOSIAL SISWA SDN 02 MOJOREJO-TAMAN-KOTA MADIUN
}

\author{
Umi Nur Halimah \\ SDN 02 Mojorejo Taman Kota Madiun \\ Email: umminurhalimah436@gmail.com
}

\begin{abstract}
Abstrak
Penelitian ini bertujuan untuk menganalisis dan mendeskripsikan dampak DOPARI terhadap sikap sosial siswa di SDN 02 Mojorejo Kecamatan Taman Kota Madiun. Metode penelitian yang digunakan adalah kualitatif deskriptif.Data yang digunakan bersumber dari data primer dan sekunder yang dianalisis menggunakan model interaktif Miles dan Huberman. Teknik pengumpulan data menggunakan wawancara, observasi, dan dokumentasi/arsip kemudian diuji kebenarannya menggunakan triangulasi sumber penelitian. Hasil penelitian menunjukkan bahwa DOPARI memiliki dampak positif terhadap sikap sosial siswa kelas IV SDN 02 Mojorejo. Para siswa lebih disiplin, ber tanggung jawab, santun, patuh pada aturan, dan percaya diri.
\end{abstract}

Kata kunci: DOPARI, Siswa Sekolah Dasar, Sikap Sosial

\section{DOPARI Impact on Social Attitude Student SDN 02 Mojorejo Taman Madiun City}

\begin{abstract}
Abtract
This study aims to analyze and describe the impact of DOPARI on students' social attitudes in SDN 02 Mojorejo Kecamatan Taman Kota Madiun. The research method used is qualitative descriptive. The data used came from primary and secondary data analyzed using Miles and Huberman interactive model. Data collection techniques using interviews, observations, and documentation / archive and then tested the truth using triangulation of research sources. The results showed that DOPARI had a positive impact on social attitude of fourth grade students of SDN 02 Mojorejo. The students are more disciplined, responsible, courteous, obedient to the rules, and confident.
\end{abstract}

Keywords:DOPARI; Elementary School Students; Social Attitudes

\section{Pendahuluan}

Pada abad ke-21 saat ini, perkembangan arus globalisasi semakin meningkat.Salah satu komponen arus globalisasi yang sangat cepat berkembang adalah teknologi. Perkembangan teknologi sendiri membawa berbagai dampak positif maupun negatif khususnya dalam dunia pendidikan. Dampak positif perkembangan teknologi yang saat ini dirasakan salah satunya adalah adanya media sosial yang memberikan kemudahan dalam berkomunikasi antar berbagai belahan dunia. Kemudahan seperti ini dapat meningkatkan komunikasi sosial positif antar keluarga maupun teman yang berada pada jarak jauh. Dampak positif perkembangan teknologi lainnya dapat kita peroleh ketika kita mampu mengelola dan 


\section{gulawentah: Jurnal Studi Sosial}

Volume 2 Nomor 2 Desember 2017 hal 130-142

Avaliable online at http://e-journal.unipma.ac.id/index.php/gulawentah

menggunakan teknologi tersebut secara bijak.

Disisi lain perkembangan teknologi juga membawa begitu banyak dampak negatif yang sulit untuk dihindari. Dalam dunia pendidikan, dampak negatif yang begitu dirasakan saat ini adalah perubahan sikap sosial siswa. Semakin maraknya tayangantayangan televisi yang dianggap menarik, penggunaan berbagai media sosial, serta kenikmatan modernisasi lainnya, secara langsung maupun tidak langsung membawa pengaruh pada perkembangan sikap sosial siswa seperti perubahan menjadi sosok individu yang mementingkan diri sendiri, menurunnya kualitas interaksi sosial antar satu dengan lainnya dan munculnya sikap sosial negatif.

Berkenaan dengan permasalahan sikap sosial siswa, di SDN 02 Mojorejo terdapat beberapa permasalahan sikap sosial yang muncul dikalangan siswamulai dari tingkat keusilan siswa didalam kelas dan sering mengganggu teman-temannya yang lain, kemudian tingkat kedisiplinan siswa yang semakin menurun terlihat dengan siswa yang datang terlambat setiap hari serta kebiasaan membuang sampah secara sembarangan terutama di loker bangku kelas. Hal ini menunjukkan sikap yang kurang disiplin dan kurang menghargai peraturan sekolah dan guru kelas. Selain itu, terdapat beberapa siswa yang nakal, suka mengganggu teman lainnya serta apabila melakukan kesalahan enggan untuk mengakui dan meminta maaf. Hal ini menunjukkan sikap yang kurang bertanggung jawab.

Permasalahan lain yang muncul adalah terdapat siswa yang kurang santun saat berkomunikasi dengan guru, tidak jarang siswa tersebut menggunakan bahasa Jawa Ngoko. Saat pembelajaran di kelas berlangsung, sebagian besar siswa juga tidak dapat menyelesaikan tugas yang diberikan guru secara tepat waktu. Hal ini dikarenakan siswa terlalu banyak bercakap-cakap dan bercanda dengan teman-teman sebangkunya sehingga menghambat mereka menyelesaikan tugas yang dibebankan. Terdapat pula siswa yang kurang percaya diri untuk tampil mempersembahkan dongeng maupun memberikan jawaban atas pertanyaan yang di lemparkan pembaca dongeng saat kegiatan DOPARI berlangsung. Hal ini terlihat ketika siswa tersebut sebenarnya mampu untuk menjawab tetapi tidak bersedia angkat tangan dan menyampaikan pendapatnya.

Didasari oleh permasalahan yang muncul tersebut, Pihak sekolah mempunyai sebuah ide yaitu mengadakan kegiatan DOPARI. DOPARI merupakan akronim dari kegiatan dongeng di pagi hari. Kegiatan positif ini dilakukan setiap hari selasa, kamis, dan sabtu (SAKATU). Kegiatan ini diikuti oleh seluruh siswa dari kelas 1 hingga kelas VI beserta seluruh jajaran guru yang ada di sekolah tersebut. Tujuan dari kegiatan ini adalah untuk menumbuhkan budi pekerti dikalangan siswa. Selain dapat 


\section{gulawentah: Jurnal Studi Sosial}

Volume 2 Nomor 2 Desember 2017 hal 130-142

Avaliable online at http://e-journal.unipma.ac.id/index.php/gulawentah

menciptakan sebuah kedekatan antara guru dengan siswa, DOPARI juga dapat menjadi sebuah sarana untuk menyampaikan sebuah pesan maupun nilai-nilai positif melalui dongeng tersebut. Hal tersebut disampaikan Hanif (2010) bahwa dongeng walaupun identik sebagai suatu cerita fiksi belaka dan rekaan, tetapi tidak berarti dongeng itu tidak bermanfaat. Dongeng memiliki potensi sebagai landasan mengembangkan rasa waktu serta kontinuitas kebudayaan yang mampu menghindarkan manusia dari kungkungan kemasakinian yang problematis.

Adapun masalah dapat dirumuskan sebagai berikut: (1) Bagaimana pelaksanaan kegiatan DOPARI di SDN 02 Mojorejo Kecamatan Taman Kota Madiun?, (2) Bagaimana dampak kegiatan DOPARI terhadap sikap sosial siswa kelas IV SDN 02 Mojorejo Kecamatan Taman Kota Madiun?. Sedangkan tujuan dari penelitian ini adalah untuk menganalisis dan mendeskripsikan pelaksanaan kegiatan DOPARI dan dampaknya terhadap sikap sosial disiplin, tanggung jawab, santun, patuh pada aturan sosial, dan percaya dirisiswa khususnya kelas IV di SDN 02 Mojorejo.

Dongeng merupakan cerita pendek kolektif kesusastraan lisan. Dongeng adalah cerita prosa yang tidak dianggap benar-benar terjadi (Fitriyyah, 2016: 5). Dongeng memiliki banyak manfaat yang bisa diambil. Media bercerita berbasis dongeng dapat menanamkan kejujuran, keberanian, kesetiaan, keramahan, ketulusan dan sikap-sikap positif yang lain dalam kehidupan lingkungan keluarga, sekolah dan luar sekolah (Moeslichatun, dalam Fitroh\&Sari, 2015:98).

Terdapat 2 unsur dalam dongeng. Pertama, unsur intrinsik terdiri dari tokoh, tema, plot/alur, gaya bahasa, sudut pandang, amanat, dan latar (Fitriyyah, 2016: 6-7). Kedua, unsur ekstrinsik yaitu nilai nilai yang terkandung dalam sastra mampu mempengaruhi perkembangan anak terutama pada hal perkembangan bahasa, kognitif, kepribadian, dan sosial. Perkembangan inilah yang diharapkan berperan baik untuk peningkatan perkembangan anak, bisa dipahami bahwa sastra tidak hanya bernilai, kognisi, imajinasi maupun kesenangan belaka melainkan mendidik (Kartika, 2015: 107).

Al-Qudsydan Nurhidayah (2010: 114-115)menyampaikan mengenai jenis-jenis dongeng diantaranya dongeng tradisional, dongeng modern, dongeng pendidikan, dongeng fabel, dongeng sejarah, dan dongeng terapi. Lebih lanjut, ide bercerita dapat digali dari berbagai sumber dapat juga berdasarkan tema yang disesuaikan dengan usia tumbuh kembang anak (AlQudsy \& Nurhidayah, 2010: 101103).Sedangkan Moesllichatoen (dalam Fitriyyah \& Zuchdi, 2014: 69) mengungkapkan beberapa macam teknik mendongeng yang dapat digunakan yaitu membaca langsung dari buku, menggunakan ilustrasi gambar, menceritakan secara langsung, 


\section{gulawentah: Jurnal Studi Sosial}

Volume 2 Nomor 2 Desember 2017 hal 130-142

Avaliable online at http://e-journal.unipma.ac.id/index.php/gulawentah

menggunakan papan flannel maupun boneka, dramatisasi dongeng hingga mendongeng sambil memainkan jarijari.

Menurut pendapat salah satu guru SDN 02 Mojorejo, Ibu Dhelly Perwita Sari, DOPARI sendiri merupakan akronim dari dongeng di pagi hari. DOPARI merupakan kegiatan mendengarkan dongeng sebagai salah satu pembiasaan yang dilaksanakan setiap hari selasa, kamis dan sabtu (SAKATU)dan diikuti oleh seluruh siswa dari kelas 1 hingga kelas VI, beserta seluruh jajaran guru yang ada di sekolah tersebut. DOPARI dilaksanakan mulai dari pukul 6.50 WIB hingga pukul 7.30 WIB. Kegiatan DOPARI ini telah dilakukan selama kurang lebih 1 oleh SDN 02 Mojorejo.Pelaksanaan kegiatan DOPARI sediri bertujuan untuk menumbuhkan budi pekerti dikalangan siswa sekaligus dapat menciptakan sebuah kedekatan antara guru dengan siswa. Hal ini sejalan dengan pendapat Desmita (2013: 188) yang menyatakan bahwa guru mengambil suatu peran sentral dalam kehidupan anak-anak, yang sangat menentukan bagaimana mereka merasakan berada di sekolah dan bagaimana mereka merasakan diri mereka.

Urutan kegiatan/proses kegiatan DOPARI dimulai dari lonceng sekolah yang berbunyi tanda berkumpul di lapangan dan siswa berbaris, kemudian menyanyikan lagu nasional secara serempak dipandu oleh musik dan siswa yang bertugas sebagai dirijen. Setelah itu pendongeng dapat menyampaikan cerita dengan perkenalan terlebih dahulu. Setelah dongeng tersampaikan, masuk pada sesi tanya jawab dan pemberian reward bagi siswa yang berani menjawab di depan. Setelah itu, guru kembali memberikan kesimpulan dan penguatan atas dongeng yang disampaikan. Ketika rangkaian kegiatan telah dilaksanakan, siswa dapat kembali ke kelas untuk menerima pelajaran.

Sikap menurut Kulsum \& Jauhar (2016: 118) adalah keadaan diri dalam manusia yang menggerakkan untuk bertindak atau berbuat dalam kegiatan sosial dengan perasaan tertentu dalam menanggapi objek situasi atau kondisi di lingkungan sekitarnya. Hanif(2014: 8-9) juga menyampaikan bahwa sikap sosial merupakan respon orang-orang sekelompoknya terhadap stimulus yang berupa obyek sosial dan dinyatakan secara berulang yang bersifat negatif atau positif. Menurut Gerungan (2010:162) sikap sosial dinyatakan dengan cara-cara kegiatan yang sama dan berulang-ulang terhadap objek sosial.

Sikap memiliki tiga komponen yang saling berhubungan yaitu komponen kognitif, komponen perasaan, dan komponen perilaku (Sears dalam Widyastuti, 2014: 59). Sedangkan Gerungan (2010: 163-164) menyampaikan ciri-ciri sikap yaitusikap tidak dibawa sejak lahir melainkan dibentuk/dipelajari, sikap dapat berubah-ubah, sikap tidak berdiri sendiri, objek sikap dapat merupakan satu hal tertentu, tetapi dapat juga 


\section{gulawentah: Jurnal Studi Sosial}

Volume 2 Nomor 2 Desember 2017 hal 130-142

Avaliable online at http://e-journal.unipma.ac.id/index.php/gulawentah

merupakan kumpulan dari hal hal tersebut, serta sikap mempunyai segisegi motivasi dan perasaan.

Walgito (dalam Mahmudah, 2012: 28-29) menyampaikan dua faktor yang dapat mempengaruhi sikap yaitu faktor internal diantaranya fisiologis dan psikologis, dan faktor eksternal diantaranya pengalaman, situasi, norma, hambatan, dan pendorong.Sedangkan menurut Rahman (2013: 131-134), proses pembentukan sikap yang terbentuk akibat proses belajar yaitu sikap terbentuk karena mengamati orang lain atau belajar sosial, sikap terbentuk karena reward-punishment, sikap terbentuk karena proses asosiasi, sikap terbentuk karena pengalaman langsung, dan sikap terbentuk melalui pengamatan terhadap perilaku sendiri.

Perkembangan sosial berarti perolehan kemampuan berperilaku yang sesuai dengan tuntunan sosial. Untuk menjadi orang yang mampu bermasyarakat, memerlukan tiga proses, yaitu belajar berperilaku yang dapat diterima secara sosial, memainkan peran sosial yang dapat diterima, dan perkembangan sikap sosial. Masingmasing proses terpisah dan sangat berbeda satu sama lain namun saling berkaitan, sehingga kegagalan dalam satu proses akan menurunkan kadar sosialisasi individu(Hurlock dalam Lestari, 2015: 28).

Pembelajaran pada kurikulum 2013, dalam pembentukan sikap siswa beracuan pada kompetensi inti sikap yang terdapat dalam kompetenti inti 1 berkaitan dengan sikap spiritual dan kompetensi inti 2 berkaitan dengan sikap sosial.Deskripsi kompetensi sikap sosial yang tercantum dalam lampiran Permendikbud No. 21 Tahun 2016 tentang Standar Isi Pendidikan Dasar dan Menengah adalah menunjukkan perilaku sebagai berikut: (1) Jujur; (2) Disiplin; (3) Santun; (4) Percaya diri; (5) Peduli dan; (6) Bertanggung jawab, Dalam interaksi dengan keluarga, teman, guru, tetangga, dan negara.

\section{Metode Penelitian}

Penelitian ini menggunakan pendekatan kualitatif dan jenis penelitian deskriptif. Subjek penelitian adalah siswa kelas IV SDN 02 Mojorejo. Penentuan informan dengan purposive sampling sedangkan data yang digunakan berasal dari sumber primer dan sekunder.

Adapun teknik pengumpulan data yang digunakan adalah observasi, wawancara, dan dokumentasi. Instrumen utama dalam pengumpulan data adalah peneliti sendiri dan instrumen bantu berupa alat rekam dan pencatat (block note), pedoman observasi dan wawancara, kamera, serta handphone dan alat tulis.Teknik keabsahan data dalam penelitian ini yaitu triangulasi sumber. Sementara teknik analisis data menggunakan model interaktif Miles dan Huberman.

\section{Hasil Penelitian dan Pembahasan}

SDN 02 Mojorejo terletak di Jalan Abdul Rahman Saleh No. 1 Kecamatan Taman Kota Madiun Provinsi Jawa Timur Kode Pos 63139.Letak SDN 02 


\section{gulawentah: Jurnal Studi Sosial}

Volume 2 Nomor 2 Desember 2017 hal 130-142

Avaliable online at http://e-journal.unipma.ac.id/index.php/gulawentah

Mojorejo terbilang strategis karena berada tidak jauh dari pusat Kota Madiun. Sekolah ini merupakan salah satu sekolah favorit di Kota Madiun karena dipercaya menjadi sekolah dasar rujukan. Artinya, sekolah ini menjadi percontohan dari sekolah-sekolah dasar lainnya.

DOPARI (dongeng di pagi hari) merupakan salah satu kegiatan positif yang dilaksanakan secara rutin pada hari selasa, kamis, dan sabtu diSDN 02 Mojorejo. Kegiatan ini memiliki banyak dampak positif bagi seluruh warga sekolah terutama bagi siswa. Pelaksanaan kegiatan ini bersifat fleksibel. Artinya, ketika pada hari-hari tersebut ada agenda lain di sekolah, maka DOPARI diliburkan.

DOPARI dilaksanakan setiap pukul 6.50 sampai 07.30 WIB oleh seluruh siswa dan guru di halaman utama SDN 02 Mojorejoselama kurang lebih satu tahun. Latar belakang yang menjadi alasan mengapa DOPARI dilaksanakan yaitu:

1. Siswa yang sering terlambat datang ke sekolah.

2. Permasalahan sikap sosial yang muncul seperti tata krama, sopan santun, minimnya kepercayaan diri, dan lain sebagainya.

3. Minat baca yang masih rendah.

4. Melatih guru dan siswa agar mahir bercerita/mendongeng.

5. SDN 02 Mojorejo yang notabene sebagai SD rujukan di Kota Madiun.

Sedangkan tujuan dilaksanakan kegiatan ini diantaranya:
1. Merubah sikap dan pola pikir siswa tentang kedisiplinan berangkat ke sekolah.

2. Sikap sosial dan tindak tanduk siswa menjadi lebih baik.

3. Menjalin kedekatan hati antara guru dan siswa.

4. Meningkatkan minat baca siswa SDN 02 Mojorejo.

5. Meningkatkan kemampuan guru dan siswa dalam bercerita/mendongeng.

Pemateri/pendongeng dalam kegiatan DOPARI sendiri melibatkan 3 pihak sekaligus secara bergilir. Pihakpihak tersebut diantaranya guru, siswa, dan orang tua siswa.Tema dongeng yang digunakan dalam kegiatan DOPARI di SDN 02 Mojorejo sifatnya bebas. Artinya, baik guru, siswa, maupun orang tua siswa bisa menceritakan dongeng apapun yang dirasa sesuai dan menarik bagi kalangan siswa. Jadi cerita saga, fabel, mitos, dan lain sebagainya bisa digunakan. Selain itu, dongeng juga dapat berasal dari cerita yang disusun sendiri. Misalnya guru bisa menciptakan dongeng sendiri dengan berlandaskan pada permasalahan dalam proses pembelajaran maupun kondisi siswa SDN 02 Mojorejo secara umum, sehingga diharapkan pesan yang disampaikan dapat diterima dan diterapkan dengan baik oleh seluruh siswa.

Rangkaian urutan kegiatannyasebagai berikut:

1. Lonceng sekolah berbunyi tanda seluruh siswa dan para guru bersiap berkumpul di lapangan. 


\section{gulawentah: Jurnal Studi Sosial}

Volume 2 Nomor 2 Desember 2017 hal 130-142

Avaliable online at http://e-journal.unipma.ac.id/index.php/gulawentah

2. Siswa berbaris rapi sesuai kelas masing-masing dipandu guru kelas.

3. Dengan menggunakan pengeras suara, guru pemandu menyampaikan nomor urut absen bagi siswa yang bertugas sebagai dirijen saat menyanyikan lagu nasional.

4. Setelah aba-aba dan musik dinyalakan, guru bersama seluruh siswa menyanyikan lagu nasional secara serempak.

5. Setelah menyanyikan lagu nasional secara baik dan benar, guru pemandu mempersilahkan siswa untuk duduk ditempat yang sama.

6. Guru pemandu mempersilahkan pemateri dongeng untuk mendongeng.

7. Perkenalan pemateri dongeng. Perkenalan dilakukan karena terkadang anak-anak kelas rendah belum mengenal jajaran guru seluruhnya. Selain itu, apabila pendongeng adalah salah satu orang tua siswa, maka tentu perkenalan penting untuk dilakukan. Hal ini mengacu pada pepatah yang menyatakan bahwa "tak kenal maka tak sayang".

8. Setelah perkenalan, pendongeng baik guru, siswa, maupun orang tua siswa dapat memulai mendongengkan suatu cerita dan siswa menyimak dongeng yang dibawakan.

9. Setelah dongeng disampaikan, pendongeng memberikan satu sampai dua pertanyaan berkaitan dengan dongeng yang disampaikan. Baik itu mengenai sikap dalam tokoh, apa yang patut ditiru atau tidak, dan lain sebagainya.

10. Siswa yang bisa menjawab dan terpilih, dapat maju ke depan untuk menyampaikan jawabannya di depan seluruh guru dan siswa lainnya.

11. Tidak jarang, guru memberikan reward atau hadiah kepada siswa yang berani menjawab di depan.

12. Ketika seluruh pertanyaan sudah terjawab, maka guru kembali memberi kesimpulan dan penguatan atas dongeng yang baru saja disampaikan.

13. Setelah seluruh rangkaian kegiatan tersebut dilaksanakan, siswa dapat kembali ke kelas masing-masing untuk menerima pelajaran.

Selain bertugas sebagai pendongeng saat mendapat giliran, guru dan siswa mempunyai peran lain, yaitu sebagai pendengar dongeng bagi siswa, dan sebagai pendamping siswa bagi guru. Secara keseluruhan, antusiasme siswa selama mengikuti kegiatan DOPARI dapat dikategorikan baik dan sangat dipengaruhi oleh bagaimana dongeng dapat disampaikan secara menarik dan tidak membosankan.Misalnya membawa alatalat peraga seperti boneka jari, selendang, dan lain sebagainya.Beberapa siswa bahkan mengajukan diri untuk dapat mendongeng di depan teman-teman dan bapak/ibu guru.

Siswa mengikuti kegiatan DOPARI secara baik dan tertib, walaupun terkadang ada beberapa siswa 


\section{gulawentah: Jurnal Studi Sosial}

Volume 2 Nomor 2 Desember 2017 hal 130-142

Avaliable online at http://e-journal.unipma.ac.id/index.php/gulawentah

yang berbicara sendiri dengan temannya ketika bapak/ibu guru tidak memperhatikan mereka. Berdasarkan hasil wawancara dengan pihak guru, siswa, dan orang tua siswa, terdapat beberapa permasalahan sikap sosial yang terjadi di SDN 02 Mojorejo seperti kedisiplinan, tanggung jawab, santun, kepatuhan pada aturan sosial, dan juga kepercayaan diri siswa. Sikap-sikap sosial tersebut dirasakan kurang berkembang dalam diri siswa SDN 02 Mojorejo khususnya siswa kelas IV.

Setelah kegiatan DOPARI dilaksanakan kurang lebih satu tahun, terdapat perbaikan/perubahan sikap sosial pada siswa secara pelan tapi pasti. Perubahan tersebut sifatnya positif, sehingga menjadikan DOPARI menjadi salah satu kegiatan favorit di SDN 02 Mojorejo.Beberapa perubahan tersebut diantaranya:

1. Sikap Sosial Disiplin

Secara umum, tingkat kedisiplinan siswa SDN 02 Mojorejo terutama kelas IV sudah meningkat seiring dengan dilaksanakannya kegiatan DOPARI. Hal ini dapat terlihat dari berkurangnya angka keterlambatan siswa. Secara keseluruhan, dulu sebelum ada DOPARI rata-rata dalamsatuhariada 25 siswa yang masihdatangterlambat, namun setelah ada DOPARI berkurang menjadi 15 siswa. Di kelas IV sendiri, keterlambatan sudah hampir tidak pernah terjadi. Kemudian kedisiplinan siswa yang semakin membaik ketika berkumpul di lapangan pada saat kegiatan DOPARI akan dilaksanakan.

2. Sikap Sosial Tanggung Jawab

Sikap sosial tanggung jawab siswa semakin terpelihara dan meningkat dengan baik.Hal ini terlihat ketika siswa melakukan kesalahan bersedia dan segera meminta maaf. Selain itu, siswa juga mau menerima resiko/hukuman atas kesalahan yang telah dilakukan.

3. Sikap Sosial Santun

Budaya santun semakin melekat dengan SDN 02 Mojorejo. Sikap sosial santun ini banyak meningkat dan telah menjadi kebiasaan yang dipelihara oleh sekolah ini yang secara tidak langsung diajarkan lewat kegiatan DOPARI yang rutin dilaksanakan.Hal ini terlihat ketika siswa bertemu dengan orang lain bersikap salam, senyum, sapa, bahkan salim. Ketika menerima bantuan/hadiah juga selalu mengucapkan terima kasih.

4. Sikap Sosial Patuh Pada Aturan Sosial

Selama satu tahun terakhir, siswa SDN 02 Mojorejo menunjukkan peningkatan dalam kepatuhannya dalam menaati peraturan disekolah seperti tidak membuang sampah sembarangan dan pemakaian seragam yang disesuaikan dengan peraturan yang berlaku.

5. Sikap Sosial Percaya Diri

Peningkatan kepercayaan diri siswa terjadi cukup signifikan, khususnya siswa kelas IV. 


\section{gulawentah: Jurnal Studi Sosial}

Volume 2 Nomor 2 Desember 2017 hal 130-142

Avaliable online at http://e-journal.unipma.ac.id/index.php/gulawentah

Dibeberapa kesempatan termasuk saat kegiatan DOPARI, secara otomatis mereka mengangkat tangan untuk menyampaikan pendapat/ jawaban dari dongeng yang disampaikan. Selain itu, keaktifan ini juga terjadi di lingkungan kelas selama kegiatan pembelajaran berlangsung, yaitu ketika siswa presentasi di depan kelas.

Sikap-sikap sosial tersebut semakin meningkat dan berkembang dengan baik dengan adanya kegiatan DOPARI. Hal ini karena pembiasaan dan pesan-pesan positif yang sering disampaikan melalui kegiatan DOPARI. Para guru dan orang tua siswa juga meresponbaik kegiatan ini untuk perkembangansikapsosialsiswakedepan. Mereka berharap kegiatan DOPARI dapat terus dibudayakan dan ditingkatkan kedepannya.

Berdasarkan paparan data di atas menunjukkan bahwa DOPARI memiliki dampak positif terhadap perubahan dan pembentukan sikap sosial siswa di SDN 02 Mojorejo.Hal ini sejalan dengan penelitian yang dilakukan Soetantyo (2013) yang meneliti tentang peranan dongeng dalam pembentukan karakter siswa sekolah dasar. Dongeng adalah sarana efektif untuk memberikan pendidikan nilai-nilai pada anak, karena penyampaiannya yang sederhana. Strategi penerapan karakter tersebut dapat dilakukan dalam empat tahap, yaitu sosialisasi, internalisasi, pembiasaan, dan pembudayaan. Dongeng adalah bagian dari budaya rakyat Indonesia. Pengaruh dongeng yang besar pun terhadap moralitas dan karakter anak-anak sangat mendukung dijadikannya dongeng sebagai cerita pendukung karakter. Dongeng dapat diberikan sebagai langkah untuk mensosialisasikan karakter yang baik yang akan diajarkan di sekolah.

DOPARI (dongeng di pagi hari) merupakan salah satu kegiatan pembiasaan mendongeng yang dilakukan secara rutin setiap hari selasa, kamis, dan sabtu oleh SDN 02 Mojorejo. Kegiatan ini dilakukan di halaman utama SDN 02 Mojorejo dengan peserta kegiatan meliputi seluruh jajaran guru dan siswa dari kelas I sampai kelas VI pada hari selasa, kamis, dan sabtu. Awal mula dilaksanakan kegiatan DOPARI di SDN 02 Mojorejo adalah tahun 2015 semester 2. Namun, kegiatan ini baru diterapkan secara rutin pada tahun 2016 semester 1. Sehingga sampai sekarang, kegiatan ini sudah ada dan dilaksanakan kurang lebih sekitar 1 tahun.

Selain dari pihak guru, dongeng juga disampaikan oleh siswa dan orang tua siswa dengan tema mendongeng yang sifatnya bebas. Artinya, baik guru, siswa, maupun orang tua bisa menceritakan dongeng apapun yang dirasa sesuai dan menarik bagi kalangan siswa. Dongeng juga dapat berasal dari cerita yang diciptakan sendiri. Misalnya guru bisa menciptakan dongeng sendiri dengan berdasarkan pada permasalahan dalam proses pembelajaran maupun kondisi siswa SDN 02 Mojorejo secara umum, sehingga diharapkan pesan yang disampaikan dapat diterima dan 


\section{gulawentah: Jurnal Studi Sosial}

Volume 2 Nomor 2 Desember 2017 hal 130-142

Avaliable online at http://e-journal.unipma.ac.id/index.php/gulawentah

diterapkan dengan baik oleh seluruh siswa. Hal ini sesuai dengan pendapat Al-Qudsy \& Nurhidayah (2010: 101103), bahwa ide bercerita dapat digali dari berbagai sumber dapat juga berdasarkan tema yang disesuaikan dengan usia tumbuh kembang anak.

Salah satu latar belakang dilaksanakannya kegiatan DOPARI adalah permasalahan sikap sosial yang terjadi dikalangan siswa SDN 02 Mojorejo. Permasalahan sikap sosial tersebut diantaranya sikap sosial disiplin, tanggung jawab, santun, patuh pada aturan sosial dan percaya diri.Dongeng sendiri memiliki berbagai manfaat positif yakni sebagai media untuk menanamkan kejujuran, keberanian, kesetiaan, keramahan, ketulusan, dan sikap-sikap positif lainnya di lingkungan keluarga, sekolah, maupun diluar sekolah (Moeslichatun dalam Fitroh\&Sari, 2015:98). Dongeng memiliki 2 unsur yang melekat, yaitu unsur intrinsik dan ekstrinsik.

\section{Dalam kegiatan DOPARI} sendiri, terdapat 5 tujuan yang ingin dicapai. Pertama, diharapkan kegiatan ini dapat merubah sikap dan pola pikir siswa tentang kedisiplinan berangkat ke sekolah. Kedua, sikap sosial dan tindak tanduk siswa menjadi lebih baik. Ketiga, pada dasarnya kegiatan ini dilakukan untuk menjalin kedekatan hati antara guru dan siswa. Keempat, meningkatkan minat baca siswa SDN 02 Mojorejo. Kelima, meningkatkan kemampuan guru dan siswa dalam bercerita/mendongeng.
Urutan kegiatan/proses kegiatan DOPARI dimulai dari lonceng sekolah yang berbunyi tanda berkumpul di lapangan dan siswa berbaris, kemudian menyanyikan lagu nasional secara serempak dipandu oleh musik dan siswa yang bertugas sebagai dirijen. Setelah itu pendongeng dapat menyampaikancerita dengan perkenalan terlebih dahulu. Setelah dongeng tersampaikan, masuk pada sesi tanya jawab dan pemberian reward bagi siswa yang berani menjawab di depan. Setelah itu, guru kembali memberikan kesimpulan dan penguatan atas dongeng yang disampaikan. Ketika rangkaian kegiatan telah dilaksanakan, siswa dapat kembali ke kelas untuk menerima pelajaran.

DOPARI merupakan salah satu objek yang dapat membentuk dan merubah sikap seseorang, sekaligus dapat dipelajari. Sikap dapat berubah karena kondisi atau pengaruh yang diberikan.DOPARI merupakan salah satu faktor eksternal kaitannya dengan kegiatan persuasi yang mempengaruhi perubahan sikap seseorang. Colman (dalam Supardan, 2013: 69) menjelaskan bahwa persuasi adalah proses pengubahan sikap yang dilakukan melalui presentasi pesan yang bermuatan argumen-argumen yang melemahkan atau menguatkan seseorang, obyek, atau isu tempat seseorang. DOPARI dapat berdampak kepada diri siswa karena respon positif yang ditunjukkan siswa mulai dari perhatian, penerimaan, dan penyimpanan pesan-pesan positif dalam 


\section{gulawentah: Jurnal Studi Sosial}

Volume 2 Nomor 2 Desember 2017 hal 130-142

Avaliable online at http://e-journal.unipma.ac.id/index.php/gulawentah

kegiatan ini. Berikut dampak DOPARI

terhadap sikap sosial siswa secara lebih rinci:

1. Sikap sosial disiplin

Sikap sosial disiplin siswa sebelum dan sesudah dilaksanakan DOPARI mengalami perubahan yang lebih baik, yaitu siswa berangkat sekolah lebih awal dan ketika DOPARI akan dimulai, siswa segera berkumpul di lapangan. Menurut Mustari (2014: 19), disiplin adalah tindakan yang menunjukkan perilaku tertib dan patuh pada berbagai ketentuan dan peraturan.

2. Sikap sosial tanggung jawab

Sikap sosial tanggung jawab siswa semakin terpelihara dan meningkat dengan baik.Lickona (dalam Fitriyyah \& Zuchdi, 2014: 72) menyampaikan bahwa tanggung jawab adalah bentuk keberanian untuk menerima semua resiko atas segala perbuatan dirinya.

3. Sikap sosial santun

Sekitar kurang lebih satu tahun kegiatan DOPARI telah dilaksanakan, budaya santun semakin melekat dengan SDN 02 Mojorejo. Sikap sosial santun ini banyak meningkat dan telah menjadi kebiasaan yang dipelihara oleh sekolah ini yang secara tidak langsung diajarkan lewat kegiatan DOPARI yang rutin dilaksanakan. Menurut Mustari (2014: 19), santun adalah sifat yang halus dan baik dari sudut pandang tata bahasa maupun tata perilakunya ke semua orang.

4. Sikap sosial patuh pada aturan sosial

Selama satu tahun terakhir, siswa SDN 02 Mojorejo menunjukkan peningkatan dalam kepatuhannya dalam menaati peraturan disekolah seperti tidak membuang sampah sembarangan dan pemakaian seragam yang disesuaikan dengan peraturan yang berlaku. Mustari (2014: 19) menyatakan bahwa patuh pada aturan sosial adalah sikap menurut dan taat terhadap aturan-aturan berkenaan dengan masyarakat dan kepentingan umum.

5. Sikap sosial percaya diri

Peningkatan sikap sosial percaya diri siswa juga terjadi cukup signifikan, khususnya siswa kelas IV. Dibeberapa kesempatan termasuk saat kegiatan DOPARI, secara otomatis mereka mengangkat tangan untuk menyampaikan pendapat/jawaban dari dongeng yang disampaikan. Selain itu, keaktifan ini juga terjadi di lingkungan kelas selama kegiatan pembelajaran berlangsung, yaitu ketika siswa presentasi di depan kelas. Mustari (2014: 19) berpendapat bahwa percaya diri adalah sikap yakin akan kemampuan diri sendiri terhadap pemenuhan tercapainya setiap keinginan dan harapan. 


\section{gulawentah: Jurnal Studi Sosial}

Volume 2 Nomor 2 Desember 2017 hal 130-142

Avaliable online at http://e-journal.unipma.ac.id/index.php/gulawentah

\section{Kesimpulan}

DOPARI merupakan akronim dari dongeng di pagi hari. Kegiatan ini telah dilaksanakan secara rutin selama kurang lebih 1 tahun pada hari selasa, kamis, dan sabtu di halaman utama SDN 02 Mojorejo. DAPORI berdampak terhadap sikap sosial siswa yaitu (a) siswa lebih disiplin berangkat sekolah dan disiplin berkumpul di lapangan untuk mengikuti DOPARI, (b) siswa lebih tanggung jawab ketika berbuat salah segera meminta maaf dan bersedia menerima resiko/hukuman ketika melakukan kesalahan, (c) siswa lebih santun ketika bertemu dengan orang lain salam, senyum, sapa dan mengucapkan terima kasih ketika mendapat bantuan/hadiah, (d) siswa lebih patuh pada aturan seperti membuang sampah pada tempatnya dan memakai seragam sesuai peraturan sekolah, (e) siswa lebih percaya diri ketika berpendapat, bertanya maupun menjawab pertanyaan.

\section{Daftar Pustaka}

Al-Qudsy, M. dan Nurhidayah, U. (2010). Mendidik Anak Lewat Dongeng. Yogyakarta: Madania.

Desmita. (2013). Psikologi Perkembangan. Bandung: PT Remaja Rosdakarya.

Fitriyyah, D. (2016). Membangun Karakter Anak Melalui Dongeng. Jurnal As-sibyān (Online). Vol. 1 (1), 6-7. (http://ejournal.uinsuka.ac.id, Diakses pada 18 Maret 2017 pukul 18.15 WIB).
Fitriyyah, D dan Zuchdi, D. (2014). Pendidikan Karakter Melalui Kegiatan Mendongeng di TK ABA Karangduwur dan TK Masyithoh Petanahan Kebumen. Jurnal Ling Tera (Online). Vol. 1 (1), 69. (http://journal.uny.ac.id/index.php /ljtp/article/view/2470,

Fitroh, S.F \& Sari, E.D.N. (2015). Dongeng Sebagai Media Penanaman Karakter Pada Anak Usia Dini. Jurnal PG-PAUD Trunojoyo (Online). Vol. 2 (2), 98.

(http://journal.trunojoyo.ac.id/pgp audtrunojoyo/article/view/2606

Gerungan. (2010). Psikologi Sosial. Bandung: PT Refika Aditama.

Hanif, M. (2010). Dongeng/Cerita Dalam Perspektif Pendidikan. Jurnal Pendidikan, 16(1).

Hanif, M. (2014). Meneropong Kampung Idiot, Perilaku Sosial Terhadap Warga Retardasi Mental Sidoharjo\&Krebet. Madiun: Institut Press IKIP PGRI Madiun

Kartika, P.C. (2015). Meningkatkan Jiwa Sosial Anak Melalui Karya Sastra Berupa Dongeng (Kajian Sastra Anak). Jurnal Stilistika (Online). Vol. 8 (2), 107. (http://journal.um-surabaya.ac.id,

Kulsum, U dan Jauhar, M. (2016). Pengantar Psikologi Sosial. Jakarta: Prestasi Pustaka.

Lestari, N.D. (2015). Identifikasi Sikap Sosial Siswa Kelas V SD. Skripsi tidak diterbitkan. Yogyakarta: 


\section{gulawentah: Jurnal Studi Sosial}

Volume 2 Nomor 2 Desember 2017 hal 130-142

Avaliable online at http://e-journal.unipma.ac.id/index.php/gulawentah

Fakultas Ilmu Pendidikan

Universitas Negeri Yogyakarta.

Mahmudah, S. (2012). Psikologi Sosial:

Teori \& Model Penelitian.

Malang: UIN-Maliki Press.

Permendikbud Nomor 21 Tahun 2016

tentang Standar Isi Pendidikan

Dasar dan Menengah (Online).

(http://bsnp-indonesia.org,

Rahman, A.A. (2013). Psikologi Sosial:

Integrasi Pengetahuan Wahyu

dan Pengetahuan Empirik.

Jakarta: PT Raja Grafindo

Persada.

Widyastuti, Y. (2014). Psikologi Sosial.

Yogyakarta: Graha Ilmu. 